\title{
Guanine-Plus-Cytosine Content of Rothia dentocariosa
}

\author{
KATHLEEN B. GUSTAFSON, ANN SEDGWICK, AND ALAN L. COYKENDALL* \\ University of Connecticut Health Center, Farmington, Connecticut 06032
}

\begin{abstract}
The guanine-plus-cytosine contents of Rothia dentocariosa strains ATCC $17931^{\mathrm{T}}$ (T = type strain) and ATCC 19426 were determined by thermal denaturation and found to be 54 and 57 mol\%, respectively. These values are lower than the values given in many publications, but are consistent with data cited in some other references.
\end{abstract}

The guanine-plus-cytosine $(\mathrm{G}+\mathrm{C})$ content of Rothia dentocariosa was reported by Hammond (4) to be 65.4 to $69.7 \mathrm{~mol} \%$, and these values are included in the description of the species in Bergey's Manual of Determinative Bacteriology, 8th ed. (1). These base contents are given in later publications which cite Hammond directly (8) or indirectly $(2,3)$. However, Slack and Gerencser $(10)$ published lower figures, 47 to $53 \mathrm{~mol} \% \mathrm{G}+\mathrm{C}$, for five strains and cited unpublished data from Hammond. These data were cited by Schaal and Pulverer (9).

To resolve this discrepancy, we determined the $\mathrm{G}+\mathrm{C}$ contents of two American Type Culture Collection strains of $R$. dentocariosa and one clinical isolate. Strains ATCC $17931^{\mathrm{T}}(\mathrm{T}=$ type strain) and ATCC 19426 were obtained from the American Type Culture Collection and were grown on casein soy agar supplemented with $10 \%$ sheep blood and in brain heart infusion broth. Small broth cultures were used to inoculate $100-\mathrm{ml}$ portions of brain heart infusion broth, which were then used to start 1-liter cultures. All cultures were tested for purity by streaking onto blood agar plates and by Gram staining. The characteristic large white colonies and pleomorphic cells were observed.

The growth of 1-liter cultures was monitored turbidimetrically for about $26 \mathrm{~h}$. Then $10,000 \mathrm{U}$ of penicillin $\mathrm{G}(10$ $\mu \mathrm{g} / \mathrm{ml}$ ) was added, and the cultures were incubated for an additional $1 \mathrm{~h}$ and harvested. The cells were suspended in 15 $\mathrm{ml}$ of $0.015 \mathrm{M} \mathrm{NaCl}$ and incubated with $10 \mathrm{mg}$ of lysozyme (Sigma Chemical Co., St. Louis, Mo.) for $1 \mathrm{~h}$ at $37^{\circ} \mathrm{C}$ and then with $200 \mathrm{U}$ of mutanolysin (Sigma) at $55^{\circ} \mathrm{C}$ for $1 \mathrm{~h}$. The suspension was made $0.15 \mathrm{M} \mathrm{NaCl}-0.0015 \mathrm{M}$ sodium citrate and heated to $60^{\circ} \mathrm{C}$, and the cells were lysed by adding $1 \mathrm{ml}$ of $25 \%(\mathrm{wt} / \mathrm{vol})$ sodium dodecyl sulfate. The deoxyribonucleic acid (DNA) was purified by phenol and chloroform deproteinizations, treatment with ribonuclease, and precipitation with ethanol (6). The yields of DNA from these slowly growing, lysis-resistant bacteria were small. About $0.5 \mathrm{mg}$ was isolated from each 1-liter culture. The values for absorbance of ultraviolet light by this DNA at 260, 230, and $280 \mathrm{~nm}$ had a ratio of 1:0.56:0.57, indicating that there was some residual carbohydrate but very little protein (6).

The $\mathrm{G}+\mathrm{C}$ contents were determined by thermal denaturation in $0.15 \mathrm{M} \mathrm{NaCl}-0.015 \mathrm{M}$ sodium citrate, using the method and formula of Marmur and Doty (7). The temperature was raised $0.5^{\circ} \mathrm{C} / \mathrm{min}$ by an automatic cuvette heater (Gilford Instrument Laboratories, Inc., Oberlin, Ohio) while the absorbance was continually recorded. The system was calibrated by simultaneous denaturation of DNA from $E s c h$ erichia coli strain $\mathrm{K}-12(51.5 \mathrm{~mol} \% \mathrm{G}+\mathrm{C}[5])$. The tempera-

\footnotetext{
* Corresponding author.
}

ture of the cuvette chamber was also calibrated by using a thermometer (Yellow Springs Instrument Co., Inc., Yellow Springs, Ohio) whose probe was inserted into the chamber. These measurements showed that the $E$. coli DNA denatured at $90.4^{\circ} \mathrm{C}(51.5 \mathrm{~mol} \% \mathrm{G}+\mathrm{C})$ when the cuvette heater registered about $91.5^{\circ} \mathrm{C}(54.1 \mathrm{~mol} \% \mathrm{G}+\mathrm{C})$. Repeated measurements with $E$. coli DNA indicated an error of $-1.07^{\circ} \mathrm{C}$, and all results were corrected by $-2.6 \mathrm{~mol} \% \mathrm{G}+\mathrm{C}$.

The $\mathrm{G}+\mathrm{C}$ content of $R$. dentocariosa ATCC $17931^{\mathrm{T}}$ was 54.1 (mol\% range for three determinations, 53.7 to 54.7 mol\%; standard deviation, $\pm 0.43 \mathrm{~mol} \%$ ), and the value for $R$. dentocariosa ATCC 19426 was 56.6 mol\% (range for three determinations, 55.8 to $57.11 \mathrm{~mol} \%$; standard deviation, $\pm 0.57 \mathrm{~mol} \%$ ). These values are only about $3 \mathrm{~mol} \%$ higher than those published by Slack and Gerenscer (10) (51 mol\% $\mathrm{G}+\mathrm{C}$ for strain ATCC $17931^{\mathrm{T}}$ ) and are far below the values in an earlier publication (4) $(69.7 \mathrm{~mol} \% \mathrm{G}+\mathrm{C}$ for the filamentous form of strain ATCC $\left.17931^{\mathrm{T}}\right)$. The value for the clinical isolate was $52.9 \mathrm{~mol} \%$ (range for four determinations, 52.0 to $53.3 \mathrm{~mol} \%$; standard deviation, $\pm 0.31 \mathrm{~mol} \%$.

Our results show that $R$. dentocarios $a \mathrm{G}+\mathrm{C}$ contents are lower than the values found in many publications (2-4) and that the lower values that have been recorded previously $(9$, 10) are credible. We believe that the data presented here should be included in future descriptions of this species.

(Details concerning the clinical isolate will be published elsewhere [M. A. Gerber et al., Lancet, in press]. The G+C contents in that report do not reflect the correction factor reported here.)

\section{LITERATURE CITED}

1. Georg, L. K. 1974. Genus V Rothia Georg and Brown, p. 679-681. In R. E. Buchanan and N. E. Gibbons (ed.), Bergey's manual of determinative bacteriology, 8th ed. The Williams \& Wilkins Co., Baltimore.

2. Goodfellow, M., and D. E. Minnikin. 1981. Classification of nocardioform bacteria. Zentralbl. Bakteriol. Parasitenkd. Infektionskr. Hyg. Abt. 1 Suppl. 11:5-16.

3. Goodfellow, M., and D. E. Minnikin. 1981. Introduction to the coryneform bacteria, p. 1811-1826. In M. P. Starr, H. Stolp, H. G. Trüper, A. Balows, and H. G. Schlegel (ed.), The prokaryotes, vol. 2. Springer-Verlag, Berlin.

4. Hammond, B. F. 1970. Deoxyribonucleic acid base composition of Rothia dentocariosa as determined by thermal denaturation. J. Bacteriol. 104:1024-1026.

5. Lovett, P. S., and F. E. Young. 1969. Identification of Bacillus subtilis NRRL B-3275 as a strain of Bacillus pumilus. J. Bacteriol. 100:658-661.

6. Marmur, J. 1961. A procedure for the isolation of deoxyribonucleic acid from microorganisms. J. Mol. Biol. 3:208-218.

7. Marmur, J., and P. Doty. 1962. Determination of the base 
composition of deoxyribonucleic acid from its thermal denaturation temperature. J. Mol. Biol. 5:109-118.

8. Mordarski, M., M. Goodfellow, K. Szyba, G. Pulverer, and A. Tkacz. 1978. Deoxyribonucleic acid base composition and homology studies on Rhodococcus and allied taxa, p. 99-106. In M. Mordarski, W. Kurylowicz, and J. Jelaszewicz (ed.), Nocardia and Streptomyces. Proceedings of the International Symposium on Nocardia and Streptomyces. Gustav Fischer
Verlag, Stuttgart

9. Schaal, K. P., and G. Pulverer. 1981. The genera Actinomyces, Agromyces, Arachnia, Bacterionema, and Rothia, p. 1921-1950. In M. P. Starr, H. Stolp, H. G. Trüper, A. Balows, and H. G. Schlegel (ed.), The prokaryotes, vol. 2. SpringerVerlag, Berlin.

10. Slack, J. M., and M. A. Gerencser. 1975. Actinomyces, filamentous bacteria. Burgess Publishing Co., Minneapolis. 